\title{
Enrichment of a Potato Flour with Isolated Soybean Protein and Non-Fat Dry Milk ${ }^{1}$
}

\author{
Edelmiro J. Rodríguez-Sosa ${ }^{2}$ \\ ABSTRACT
}

Mashed potato samples were enriched with isolated soybean protein (ISP) and skim milk (SM) at 5 and $10 \%$, and a combination of these levels. As expected, the increase in protein level was greater when ISP was added. Protein content of samples ranged from $7.70 \%$ in the standard sample to $17.60 \%$ when a combination of $10 \%$ ISP and $10 \%$ SM was added. SM increased firmness and gumminess, whereas ISP decreased firmness of samples. ISP added at a $5 \%$ level slightly improved the appearance of the mashed potatoes. ISP added at a $5 \%$ level and SM at 5 and $10 \%$ levels increased the acceptability of the samples.

\section{INTRODUCTION}

Protein malnutrition is a serious problem in areas such as Asia, Africa and Latin America. It has been estimated that about one-half of the world population is suffering from an inadequate protein intake. The problem is most serious for children from weaning age to school age (1 to 7 years); however, this protein deficiency affects people of all ages in the above mentioned areas.

Several laboratories have been developing vegetable and fish protein foods for supplementary feeding as a means of controlling protein malnutrition (9). Isolated soybean protein (ISP) can be readily introduced into a wide variety of foods and consequently can significantly increase protein intake. Since starchy vegetables, including potatoes, appear frequently in the daily diet of people living in those areas they are logical carrier foods for ISP.

Potatoes are a universal agricultural crop (15). They have been dehydrated in many physical forms $(3,4,6,7)$.

Soybean and its products have been used as an important source of protein in the diet of oriental people for thousands of years (11). Continuous emphasis is being given to this crop because it can be grown economically under a wide range of soils and climatic conditions (8).

ISP is prepared by extracting undenatured soybean flour with water or dilute alkali to separate the proteins from the insoluble polysaccharides (1). After removal of the insoluble residues, most of the protein is

${ }^{1}$ Manuscript submitted to Editorial Board September 29, 1982.

${ }^{2}$ Food Technologist, Food Technology Laboratory, Agricultural Experiment Station, Mayagüez Campus, University of Puerto Rico, Rio Piedras, P. R. The author dedicates this publication to the memory of the late Amihud Kramer, his professor at the University of Maryland. 
recovered from the aqueous extract by adjusting the $\mathrm{pH}$ to the isoelectric point of the globulines so that they become insoluble and hence precipitate. For drying, spray or drum driers are used (13). Non-fat dry milk or skim milk (SM) is produced extensively the world over.

Soybean protein is deficient in sulfur containing amino acids, but it is a good source of lysine $(14,5)$. It has also been found that methionine deficiency can be overcome in practical diets by the addition of very small amounts of the synthetic amino acid (5).

The purpose of this study was to investigate the possibility of increasing the protein content of potato flour with ISP, which could then be used in areas where protein malnutrition prevails.

\section{MATERIALS AND METHODS}

Commercial instant mashed potato flakes were used in the preparation of samples. Extra grade commercial SM with a protein content of $32.89 \%$ $(\mathrm{N} \times 6.25)$ and an ash content of $7.88 \%$ dry basis, and ISP Supro 610 (Ralston Purina Co.) $)^{3}$ were used to enrich the mashed potatoes. This ISP is specially formulated for instant foods and has a protein content of $95 \%(\mathrm{~N} \times 6.25)$.

Eight 1-lb. samples with ISP and/or SM added and standard 100\% instant mashed potatoes, were prepared as follows:

$\begin{array}{ccc}\text { Samples } & \begin{array}{c}\text { ISP } \\ \text { added } \\ \%\end{array} & \begin{array}{c}\text { Skim milk } \\ \text { added }\end{array} \\ \mathbf{1} & 0 & \% \\ 2 & 5 & 0 \\ 3 & 0 & 0 \\ 4 & 5 & 5 \\ 5 & 10 & 5 \\ 6 & 0 & 0 \\ 7 & 10 & 10 \\ 8 & 10 & 10 \\ 9 & 5 & 5\end{array}$

Mashed potatoes, ISP and/or SM, and table salt at 3\% level were mixed thoroughly for $30 \mathrm{~min}$ in a ball mill. After being mixed, samples were stored at room temperature in tightly closed amber jars.

\footnotetext{
${ }^{3}$ Trade names in this publication are used only to provide specific information. Mention of a trade name does not constitute a warranty of equipment or materials by the Agricultural Experiment Station of the University of Puerto Rico, nor is this mention a statement of preference over other equipment or materials.
} 
All chemical analyses were performed on a dry weight basis. Protein, ash, and ether extracts, and moisture analyses were performed according to A.O.A.C. (2). The results of protein analyses were expressed as $\%$ protein $(\mathrm{N} \times 6.25)$.

Shear press and color analyses were taken on samples prepared as for sensory evaluations. Temperature of samples in both analyses was maintained at $83^{\circ} \mathrm{F}+2^{\circ} \cdot\left(28.3^{\circ}\right)$. For the shear press analyses, $150 \mathrm{~g}$ samples were used. A Shear Press modified for recording and speed control on both down and up strokes was used. A 100-lb proving ring and a Hartman or back extrusion cell (10), which has a solid bottom and a loosely fitted plunger were used with the shear press system. The stroke of the shear press plunger was adjusted to 30 seconds and the recorder to a range of $50 \%$. Maximum peak was read directly from the obtained chart and the area under the curve measured with a planimeter. We also recorded for each down strokes curve a point at which the separation between the line descending after the point of maximum and the ascending line reached one inch. Color measurement of samples were taken with a Hunter Lab Model D-25 Color Difference Meter.

Sensory evaluations were conducted to evaluate the acceptability of the product. Samples were analyzed for appearance, flavor, mouth feel (texture) and overall acceptability. A 6-point hedonic scale ranging from highly acceptable - 6 - to unacceptable - 1 - was used.

Samples were presented as mashed potatoes to the panelists. To prepare them, $230 \mathrm{ml}$ boiling tap water was added to $53 \mathrm{~g}$ of each of the previously prepared formulas placed in nine $600-\mathrm{ml}$ beakers. They were allowed to stand for $1 \mathrm{~min}$ and then mixed thoroughly, stirred 50 times with a fork. Samples were allowed to cool for about $20 \mathrm{~min}$ and then submitted to sensory evaluations. The 9 samples were presented at one sitting in a randomized form. A panel of 10 persons participated in the sensory evaluation.

The obtained data was statistically analyzed with Duncan's Multiple Range Test. The correlation coefficients were computed by the ranking method (12).

\section{RESULTS}

Table 1 shows the protein, ash, fat and moisture analyses of the 9 mashed potato samples. As expected, the protein content of the samples varied according to the amount of ISP and SM added. The protein content of the standard sample ( $100 \%$ mashed potato) was $7.70 \%$. As anticipated, every percentage of ISP added increased protein by almost $0.8 \%$, whereas $1.0 \%$ of SM added increased protein of the mashed potato only about $0.3 \%$. Thus sample $3(5 \% \mathrm{SM})$ had the lowest increase in 
protein over the standard sample; whereas the highest increase was obtained in sample 7 (10\% ISP $+10 \%$ SM). Ash content in samples, ranging from 6.14 to $5.00 \%$, was higher in samples with ISP added. The fat content was very low in all samples.

Table 2 shows the results of shear press analyses. The analysis of variance for maximum force and area under the curve for both down and up curves showed significant differences in level of addition of ISP and SM among samples. The smooth shear press curves indicated the uniformity of the product (fig. 1). Very sharp slopes in the descending section of the curves indicated the low degree of adhesiveness of the mashed potato samples. In both, down and up strokes curves, the sample

TABLE 1.-Proximate composition of the dry ingredients ${ }^{1}$ and moisture content ${ }^{2}$ of mashed potato samples

\begin{tabular}{|c|c|c|c|c|c|}
\hline Code & $\begin{array}{l}\text { Sample } \\
\text { formula }\end{array}$ & $\begin{array}{c}\text { Protein } \\
(\mathrm{N} \times 6.25)\end{array}$ & Ash & $\begin{array}{c}\text { Fat } \\
\text { (ether } \\
\text { extract) }\end{array}$ & Moisture \\
\hline 1. & $100 \%$ potato & 7.70 & 5.09 & 0.57 & 80.31 \\
\hline 2 & $5 \%$ ISP & 11.99 & 5.91 & 0.60 & 81.65 \\
\hline 3 & $5 \%$ skim milk & 9.67 & 5.00 & 0.53 & 79.96 \\
\hline 4 & $\begin{array}{l}5 \% \text { ISP }+5 \% \\
\text { skim milk }\end{array}$ & 12.51 & 5.63 & 0.50 & 80.26 \\
\hline 5 & $10 \%$ ISP & 15.42 & 6.14 & 0.63 & 80.74 \\
\hline 6 & $10 \%$ skim milk & 10.38 & 5.22 & 0.68 & 78.93 \\
\hline 7 & $\begin{array}{l}10 \% \text { ISP }+10 \% \\
\text { skim milk }\end{array}$ & 17.60 & 6.03 & 0.74 & 79.14 \\
\hline 8 & $\begin{array}{l}10 \% \text { ISP }+5 \% \\
\text { skim milk }\end{array}$ & 15.60 & 5.48 & 0.68 & 80.15 \\
\hline 9 & $\begin{array}{l}5 \% \text { ISP }+10 \% \\
\text { skim milk }\end{array}$ & 13.48 & 5.42 & 0.67 & 79.21 \\
\hline
\end{tabular}

${ }^{1}$ Dry weight basis.

${ }^{2}$ Fresh weight basis.

having $10 \%$ SM was the firmest, followed by the sample with 5\% SM added. Sample 5 (10\% ISP) was the softest and the least gummy. The standard sample and sample 2 (5\% ISP) had practically the same shear press values in both the down and up strokes. In summary, SM increased firmness and gumminess, while ISP decreased firmness of the product.

Table 2 also shows the above-mentioned point on the ascending line of the down stroke curve. Figure 1 illustrates how this measurement was taken. Sample 6 recorded the highest peak of force followed by sample 3; sample 5 yielded the lowest value. These values correspond to the firmest and gummiest samples, respectively. The peak force of the standard sample and that of sample 2 were about the same, indicating similar firmness. The results of the shear press tests in this case also clearly 
show that SM serves to increase the firmness of the product, whereas ISP decreases firmness. The analysis of variance of this data showed significant differences among treatments. Sample 5 was significantly low at the $5 \%$ level. There were no significant differences between samples prepared with combinations of ISP and SM.

Table 3 shows the color data. The highest value for lightness $(L)$ was obtained for the sample with $10 \%$ SM added, whereas the lowest value was obtained when $10 \%$ ISP was added. However, the range for the 9 samples was low (1.13), indicating that there were no great variations in lightness among samples.

Table 4 shows the results of sensory evaluations. Some significant differences were found among levels of additions of ISP and SM, and

TABLE 2.-Shear press values for mashed potato samples

\begin{tabular}{|c|c|c|c|c|c|}
\hline \multirow[b]{2}{*}{ Code } & \multicolumn{2}{|c|}{ Down stroke } & \multicolumn{2}{|c|}{ Up stroke } & \multirow{2}{*}{$\begin{array}{c}\text { Down stroke } \\
\text { Force }^{1}\end{array}$} \\
\hline & $\begin{array}{l}\text { Maximum } \\
\text { force }\end{array}$ & $\begin{array}{l}\text { Area under } \\
\text { the curve }\end{array}$ & $\begin{array}{l}\text { Maximum } \\
\text { force }\end{array}$ & $\begin{array}{l}\text { Area under } \\
\text { the curve }\end{array}$ & \\
\hline & lbs & sq. in. & lbs & sq. in. & lbs \\
\hline 1 & 23.17 & 1.35 & 7.67 & 0.96 & 18.00 \\
\hline 2 & 23.00 & 1.33 & 7.73 & 1.00 & 18.60 \\
\hline 3 & 25.57 & 1.49 & 8.47 & 1.11 & 19.03 \\
\hline 4 & 21.70 & 1.18 & 7.90 & 0.97 & 17.67 \\
\hline 5 & 20.77 & 1.18 & 6.30 & 0.83 & 15.80 \\
\hline 6 & 25.67 & 1.64 & 10.00 & 1.31 & 21.50 \\
\hline 7 & 22.17 & 1.27 & 7.67 & 0.97 & 16.17 \\
\hline 8 & 24.53 & 1.40 & 7.80 & 0.98 & 17.93 \\
\hline 9 & 21.97 & 1.26 & 8.27 & 1.04 & 17.27 \\
\hline
\end{tabular}

${ }^{1}$ Force value of the point at which the separation between the line descending after the point of maximum force and the ascending line reaches one inch.

among replications in the appearance of the mashed potato samples. Thus, samples 2 and 6 had the higher scores, but they differed significantly from each other and from all other samples. All samples were accepted for the attribute of appearance; sample 5, which received the lowest score (4.6), was between acceptable and slightly acceptable. These substantial differences in appearance compared to the small differences in Hunter color values indicate that panel evaluation of appearance was not explained on the basis of color alone.

The addition of 5\% ISP and 10\% SM improved slightly the appearance of the mashed potato over the standard sample. When SM was added at a $5 \%$ level appearance was scored equal to that of the standard sample, but at the $10 \%$ ISP level it was reduced significantly. It appears that the addition of ISP improves the appearance of the sample to a certain maximum point, but that further addition of the isolated protein detracts 
from appearance. This relation was also true for mixtures of ISP and SM.

Sample 5 was scored between slightly acceptable and neither acceptable nor unacceptable for flavor (table 4). However, samples 1, 2, 3, and 6 were significantly better and were scored between acceptable and slightly acceptable. When 10\% ISP was added to the mashed potatoes, the flavor

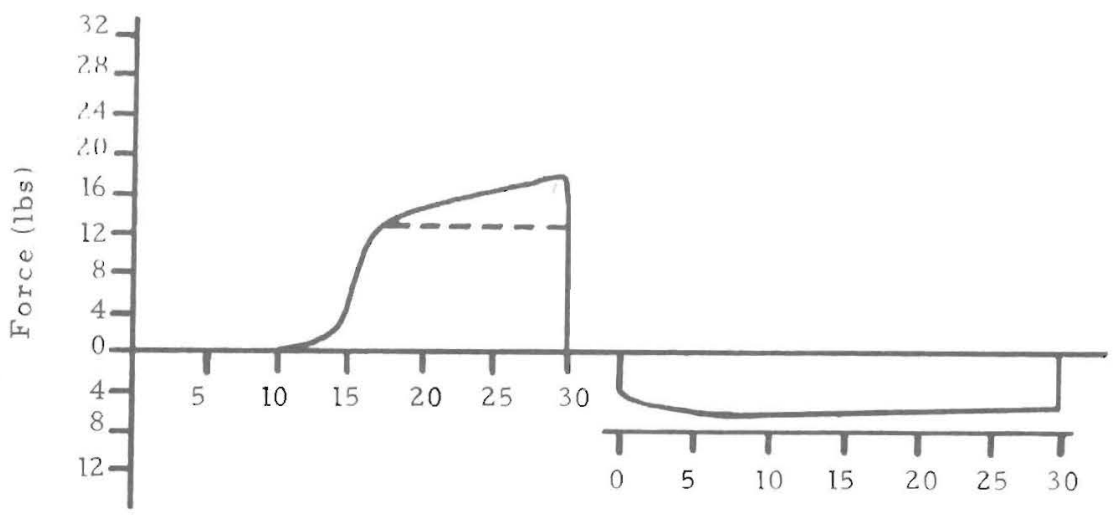

Chart travel (seconds)

FIG. 1.-Typical shear press curve of the down and up stroke of mashed potatoes enriched with isolated soybean protein and/or skim milk.

TABLE 3.-Hunter color difference meter value for mashed potato samples

\begin{tabular}{clrcr}
\hline \multirow{2}{*}{ Sode } & \multicolumn{3}{c}{ Mean values formula } & \multicolumn{3}{c}{} \\
\cline { 3 - 5 } & & $L^{1}$ & $a$ & $b$ \\
\hline 1 & $100 \%$ protein & 74.2 & -2.3 & 12.8 \\
2 & $5 \%$ ISP & 74.3 & -2.1 & 12.3 \\
3 & $5 \%$ skim milk & 74.5 & -2.1 & 12.7 \\
4 & $5 \%$ ISP + 5\% skim milk & 73.5 & -1.9 & 12.4 \\
5 & $10 \%$ ISP & 74.8 & -2.4 & 12.4 \\
6 & $10 \%$ skim milk & 73.9 & -1.8 & 12.3 \\
7 & $10 \%$ ISP + 10\% skim milk & 74.1 & -2.0 & 12.9 \\
8 & $10 \%$ ISP + 5\% skim milk & 74.1 & -2.1 & 12.5 \\
9 & $5 \%$ ISP + 10\% skim milk & 1.3 & 0.6 & 1.1 \\
\hline
\end{tabular}

${ }^{1} L=$ lightness; $-a=$ greenness; and $b=$ yellowness.

was considerably less acceptable than that of the standard sample. However, when $10 \%$ SM was added together with $10 \%$ ISP, no significant difference was observed between the two. This acceptability was lower for sample 8, but still no significant difference was observed; thus, SM apparently enhanced the flavor of the product.

Mouth feel scores (table 4) indicated that all samples, except sample 
5 , were between acceptable and slightly acceptable. Sample 5 was between slightly acceptable and neither acceptable nor unacceptable. Thus, addition of SM improved the desirable qualities of texture of mashed potato samples, whereas ISP beyond the $5 \%$ level lowered texture quality. Samples 2 and 5 were significantly different.

The highest scores for overall acceptability were for samples prepared with the addition of $5 \%$ ISP and $5 \% \mathrm{SM}$, followed by the sample prepared with $10 \%$ SM (table 4). There were no significant differences between acceptability scores of these samples and that of the standard sample. Sample 2 was significantly better than sample 5 , an indication that ISP up to $5 \%$ and SM at 5 and $10 \%$ levels improve the acceptability of the mashed potato. Samples prepared with combinations of ISP and SM scored below the standard samples.

TABLE 4.-Mean score values of mashed potato samples for sensory evaluations ${ }^{1}$

\begin{tabular}{clcccc}
\hline Code & \multicolumn{1}{c}{ Sample formula } & Appearance & Flavor & $\begin{array}{c}\text { Mouth } \\
\text { feel }\end{array}$ & $\begin{array}{c}\text { Overall } \\
\text { accept- } \\
\text { ability }\end{array}$ \\
\hline 1 & $100 \%$ potato & 5.00 & 4.50 & 4.55 & 4.45 \\
2 & $5 \%$ ISP & 5.20 & 4.45 & 4.80 & 4.70 \\
3 & $5 \%$ skim milk & 5.00 & 4.55 & 4.70 & 4.70 \\
4 & $5 \%$ ISP + 5\% skim milk & 4.95 & 3.90 & 4.00 & 4.30 \\
5 & 10\% ISP & 4.60 & 3.50 & 3.90 & 3.70 \\
6 & $10 \%$ skim milk & 5.10 & 4.45 & 4.50 & 4.50 \\
7 & 10\% ISP + 10\% skim milk & 4.65 & 4.00 & 4.10 & 4.00 \\
8 & 10\% ISP + 5\% skim milk & 4.75 & 3.75 & 4.20 & 4.30 \\
9 & $5 \%$ ISP + 10\% skim milk & 4.65 & 4.10 & 4.40 & 4.20 \\
\hline
\end{tabular}

${ }^{1}$ Using a 6-point hedonic scale ranging from highly acceptable to unacceptable: 6 , like very much; 5 , like; 4 , like moderately; 3 , neither like nor dislike; 2 , dislike a bit, 1 , dislike.

Appearance is one of the most important factors in determining the acceptability of a product. This study found that the higher values of appearance corresponded to the higher values of overall acceptability in the samples $(r=0.95)$.

The appearance of the mashed potato samples was enhanced with the addition of SM at both levels; even more important was the finding that ISP also improved the appearance of the product when added at a level of $5 \%$.

The correlation coefficient between Hunter color measurement for $L$ and appearance was 0.83 . All samples were accepted for appearance. Supposedly, samples with higher $L$ values would be more acceptable than those with lower $L$ values.

Higher values for mouth feel resulted in higher overall acceptability scores $(r=0.88)$. The addition of $5 \%$ ISP to the mashed potato improved the desirable texture characteristics of the product. This texture improve- 
ment was also true for the addition of $5 \%$ SM. However, when $10 \%$ ISP was added these qualities diminished.

The correlation coefficient for down stroke shear press between mouth feel and maximum force exerted (0.67), and between mouth feel and area under the curve (0.66) were not particularly high. The correlation between overall acceptability and maximum force, and that between overall acceptability and area under the curve were also low, 0.73 and 0.70 , respectively. For the up stroke curve the correlation coefficients were even lower. However, the correlation between mouth feel and the point on the ascending curve was 0.80 (tables 2 and 4). The correlation coefficient between this point and the overall acceptability of the product was even higher, 0.94 . Since this measurement is essentially a measurement of the slope of the ascending curve, it may be assumed to be a measure of firmness, or elasticity within the limits of this study; the firmer and less elastic, the better. Obviously, if the product is too firm it will be rejected.

The correlation coefficient between flavor and overall acceptability was 0.79 , lower than the correlation between overall acceptability and the attributes of appearance and mouth feel.

\section{CONCLUSION}

The main conclusion derived from this study is that it is possible to replace skim milk (SM) or milk solids in the preparation of mashed potatoes with isolated soybean protein (ISP) as a means of enrichment. In the case of the substitution with $5 \%$ ISP, the mashed potato product was found to be as good or better than the product prepared in the usual way, that is, with the addition of milk only. This possibility of substitution of ISP for milk has two important implications: ISP is cheaper than $\mathrm{SM}$, and it adds more protein to the mashed potatoes.

These two implications are of vital importance in the introduction of such a product in developing countries where protein malnutrition exists.

Regarding the texture of the mashed potato product, SM tends to increase firmness, whereas ISP tends to decrease firmness.

\section{RESUMEN}

Varias muestras de harina instantánea de papas se enriquecieron a distintos niveles con proteína aislada de soya (ISP) y leche desnatada (SM). Un grupo de catadores analizó y evaluó sensorialmente las muestras. Los niveles de adición de ISP y SM fueron al 5 y $10 \%$, y combinaciones de éstos. Como se esperaba, el aumento en el contenido de proteína fue mayor cuando se añadió ISP.

La SM tendió a aumentar la gomosidad y consistencia de las muestras, mientras que la ISP tendió a disminuir la consistencia. La muestra con 
$10 \%$ de SM fue la más firme, seguida por la nuestra que contenía $5 \%$ de SM.

La adición de ISP al 5\% mejoró ligeramente la apariencia de la harina instantánea. La ISP a un nivel de 5\% y la SM a uno de 5 ó a $10 \%$ mejoraron la aceptabilidad general de las papas majadas instantáneas.

\section{LITERATURE CITED}

1. Altschul, A. M., Ed, 1958. Processed plant protein foodstuffs, Chap. 10, 11, and 15, Academic Press, N. Y.

2. Association of Official Agricultural Chemists, Official Methods of Analyses, 1970, 11th ed, Washington, D. C.

3. Barker, J., Burton, W. G. and Gane, R., 1943. Mashed Potato Powder. I. Properties and methods of productions, Great Britain Dep. Sci. Ind. Res, and Ministry of Food Dehydration. United Kingdom Prog. Rep., sec. VI, part 6.

4. Bowen, W. S., 1931. Spray-drying Idaho's surplus potatoes, Food Inds. 3: 380-3.

5. Bressani, R., Elias, L. G., 1968. Processed vegetable protein mixture for human consumption in developing countries, Advances in Food Research, 16: 1-103.

6. Burton, W. G., 1944. Mashed Potato Powder. II. Spray-drying method, J. Soc. Chem. Ind. $63: 213-5$.

7. Cording, J., Jr., Willard, M. J., Eskew, R. W., Jr. and Edwards, A. W., 1954. Potato flakes, a new form of dehydrated mashed potatoes. I. Pilot-plant process using double drum driers. USDA, ARS Circ. ARS 73-2.

8. Diser, G. M., 1961. Soy flour and soy grits as protein supplements for cereal products, Proc. Conf. Soybean Products for Protein, USDA, ARS 7-22: 52.

9. Dutra de Olivera, J. E. and Scalina, L., 1967. Nutritional value of protein from soybean milk powder, J. Food Sci. 32: 592-4.

10. Hartman, J. D., Isenberg, F. M., and Ang, J. K., 1963. New applications of the shear press in measuring texture in vegetables and vegetable products, Proc. Am. Soc. Hort. Sci., 82: 465.

11. Hayward, J. W. and Diser, G. M., 1961. Soybean protein as a soy flour and grits for improving dietary standards in many parts of the world, Soybean Digest 21 (10): 1423.

12. Kramer, A. and Twigg, B. A., 1966. Fundamentals of quality control for the food industry, The AVI Publishing Co., Westport, CT.

13. Meyer, E. W., 1967. Soy protein concentrates and isolates, Proc. of Intern. Conf. on Soybean Protein Foods, Peoria, Ill., 1966, ARS 71-35, pp 112-28.

14. Milner, M., 1966. General outlook for seed protein concentrates, World Protein Resources, Adv. Chem. Ser. 57: 56-64.

15. Szebiotko, K., 1965. Total utilization of potatoes including the disposal of industrial wastes. Record 4. Proc. Inter. Symp., Utilization and Disposal of Potato Waste, N. B. RPC, Fredericton, N. B., Canada, pp. 30-49. 